\title{
PEMBELAJARAN MATEMATIKA PADA ANAK BERKEBUTUHAN KHUSUS (ABK) TIPE SLOW LEARNERS
}

\author{
Muhammad Hairul Saleh, Dina Huriaty, Arifin Riadi \\ Pendidikan Matematika STKIP PGRI Banjarmasin \\ Salehbale3@gmail.com,dina_rty@yahoo.com, arifin.riadi@stkipbjm.ac.id
}

\begin{abstract}
Abstrak: Tujuan penelitian ini adalah untuk mendeskripsikan pembelajaran matematika pada anak berkebutuhan khusus di kelas inklusif SMPN 5 Banjarbaru. Metode penelitian ini menggunakan metode deskriptif kualitatif. Subjek penelitian ini adalah guru matematika, GPK dan siswa ABK. Sedangkan objek penelitian ini adalah proses pembelajaran matematika pada materi lingkaran. Teknik pengumpulan data dalam penelitian ini adalah menggunakan observasi dan wawancara. Hasil penelitian ini antara lain sebelum pembelajaran berlangsung, guru matematika telah menyiapkan RPP, silabus, media pembelajaran dan buku paket sebagai sumber belajar. GPK hanya bertugas menyiapkan media, sumber belajar dan siswa ABK slow learners itu sendiri. Dalam pelaksanaan pembelajaran Guru matematika menyiapkan siswa secara psikis dan fisik, memberitahukan materi yang akan dibahas dan mengajukan beberapa pertanyaan, serta menggunakan beragam pendekatan. Guru matematika memfasilitasi terjadinya interaksi di dalam kelas, serta selalu memantau dan membimbing ABK, kemudian bersama seluruh siswa membuat rangkuman atau kesimpulan pelajaran dan melakukan penilaian untuk seluruh siswa, serta memberikan umpan balik terhadap proses dan hasil pembelajaran. GPK bertugas menjelaskan kembali kepada siswa ABK slow learners tentang apa saja yang disampaikan guru matematika di depan kelas,serta bertugas menilai siswa ABK. Setelah pembelajaran berakhir Guru matematika dan GPK menyampaikan materi selanjutnya, rencana pembelajaran berikutnya dan memberikan tugas kepada siswa biasa dan siswa ABK.
\end{abstract}

Kata Kunci: Pembelajaran Matematika, Anak Berkebutuhan Khusus(ABK), Kelas Inklusif

\section{Pendahuluan}

Pendidikan inklusif merupakan pendidikan reguler yang diberikan kepada Anak Berkebutuhan Khusus (ABK) untuk belajar bersama anak normal lainnya. Dengan pendidikan inklusif ini siswa ABK akan dididik bersama anak-anak normal untuk dapat merasakan pendidikan yang sama dengan yang lainnya. Diharapkan pendidikan inklusif ini dapat menutup adanya kemungkinan terjadinya diskriminasi terhadap $\mathrm{ABK}$, sehingga anak itu dapat belajar hidup di lingkungan masyarakat pada umumnya, dan pembelajaran ini dapat dimulai dari masyarakat sekolah.
SMPN 5 Banjarbaru adalah salah satu sekolah yang menerapkan pendidikan inklusif bagi siswa ABK. Sekolah ini memiliki satu siswa ABK dan telah meluluskan beberapa siswa ABK lainnya, mereka selama tiga tahun telah merasakan belajar bersama-sama anakanak normal. Pada tahun pembelajaran 20162017 ini hanya terdapat satu siswa ABK yang dalam kategorinya termasuk lamban belajar (slow learners).

"Lamban belajar (slow learner), keterbatasan anak learning disability adalah rata-rata prestasi belajarnya selalu rendah, terlambat dalam menyelesaikan tugas akademik, daya tangkap pembelajaran 
lambat”.(Ngadimun et.al, 2013: 25-26)“. Sedangkan menurut Kustawan (2012: 29), "Anak lamban belajar (slow learner) adalah anak yang memiliki potensi intelektual sedikit dibawah normal tetapi belum termasuk tunagrahita". Dalam hal ini anak slow learners seharusnya mendapatkan waktu yang lebih lama dari pada yang lain untuk menyerap pembelajaran yang diberikan oleh guru serta perbanyak latihan dari pada hafalan dan diperbanyak kegiatan remedial, sehingga memerlukan pelayanan pendidikan khusus. Dalam pelayanan ini diperlukannya seorang guru khusus untuk mendampingi siswa ABK, karena seorang slow learners membutuhkan seseorang yang khusus membimbingnya untuk memberikan pemahaman-pemahaman materi yang disampaikan oleh guru mata pelajaran. Fungsi ketersediaan Guru Pendamping Khusus (GPK) dalam kelas inklusif sangat penting, karena anak slow learners pastinya akan membuat proses pembelajaran dalam kelas menjadi sedikit terganggu. Menurut hasil penelitian Setyowati (2014), pada kelas XI Seni Lukis, XI MMC, XI MMA, dan XI Animasi SMK N 9 Surakarta, pembelajaran lebih ditekankan pada latihan-latihan soal oleh guru tanpa terlebih dahulu memberikan konsep yang tepat dalam pembelajaran mengakibatkan kurangnya pemahaman konsep pada ABK dalam belajar matematika dibanding dengan siswa normal lainnya, hal ini juga dikarenakan tidak tersedianya GPK saat pembelajaran berlangsung yang bertugas sebagai jalur komunikasi guru mata pelajaran dengan siswa ABK. Artinya fungsi dari GPK sangat penting dalam pendidikan inklusif, karena seorang GPK dapat membantu interaksi antara guru dengan siswa ABK.

Dalam penerapan pendidikan inklusif harus memiliki kesiapan dalam segala hal, termasuk dari siswanya itu sendiri yaitu siswa biasa maupun $\mathrm{ABK}$ juga harus mempunyai kesiapan mental dalam belajar di kelas inklusif pada saat proses pembelajaran tidak terkecuali dalam pembelajaran matematika.

Menurut Hudojo (Hasratuddin, 2014: 30), "matematika merupakan ide-ide abstrak yang diberi simbol-simbol itu tersusun secara hirarkis dan penalarannya deduktif, sehingga belajar matematika itu merupakan kegiatan mental yang tinggi." Sedangkan menurut James dalam kamus matematikanya (Hasratuddin, 2014: 30), "Matematika adalah ilmu tentang logika mengenai bentuk, susunan, besaran dan konsep-konsep berhubungan lainnya dengan jumlah yang banyak yang terbagi kedalam tiga bidang, yaitu aljabar, analisis dan geometri."

Sebagai salah satu pembelajaran yang sulit, tidak heran apabila siswa mengalami berbagai kesulitan dalam belajar matematika tidak terkecuali untuk siswa ABK yang mungkin akan mengalami beberapa kesulitan dalam belajar matematika. Oleh karena itu, sebagai guru matematika yang dibantu guru pembimbing khusus harus dapat memberikan penyelesaian yang baik agar kendala-kendala yang dialami $\mathrm{ABK}$ tersebut tidak terjadi lagi saat proses pembelajaran selanjutnya. Kendala-kendala yang dialami ABK jenis slow learners kemungkinan akan sangat terlihat saat proses pembelajaran, anak ini selalu membutuhkan waktu yang lama untuk menyerap pembelajaran matematika, untuk itulah kesiapan yang matang dalam pembelajaran matematika pada siswa ABK di kelas inklusif ini agar mendapatkan hasil yang maksimal. Pembelajaran di kelas inklusif melalui beberapa tahapan, yaitu: (1) kesiapan sebelum pembelajaran; (2) pelaksanaan pembelajaran; (3) evaluasi dan tindak lanjut. 


\section{Metode Penelitian}

Penelitian ini menggunakan jenis penelitian deskriptif dengan pendekatan kualitatif, karena data yang akan diperoleh bukan berupa angka-angka, namun berupa catatan-catatan lapangan dan hasil wawancara. Hal ini bertujuan untuk menggali informasi mengenai pelaksanaan pembelajaran matematika di kelas inklusif. Dengan pendekatan kualitatif diharapkan dapat memberikan gambaran yang jelas tentang pembelajaran matematika di kelas inklusif.

Waktu penelitian ini dilaksanakan pada bulan januari 2016 semester genap tahun ajaran 2016-2017. Lokasi penelitian ini akan dilaksanakan di SMPN 5 Banjarbaru.

Subjek penelitian ini adalah guru mata pelajaran matematika kelas VIIIC SMPN 5 Banjarbaru tahun pelajaran 2016-2017 dan GPK, serta siswa ABK. Sedangkan objek penelitian ini adalah proses pembelajaran Matematika pada materi lingkaran.

Dalam penelitian ini yang menjadi datanya adalah berupa informasi tentang pembelajaran matematika di kelas inklusif yang meliputi kesiapan guru matematika dan GPK sebelum pembelajaran, pelaksanaannya dan evaluasi serta tindak lanjutnya, juga tentang faktor atau kendala yang dialami siswa ABK saat pembelajaran berlangsung. Dimana Informasi-informasi tersebut akan diperoleh melalui observasi dan wawancara terhadap guru matematika, GPK dan siswa ABK.

Teknik pengumpulan data dalam penelitian ini adalah menggunakan observasi dan wawancara. Teknik analisis data dalam penelitian ini menggunakan teknik deskriptif yang sebelumnya dilakukan validitasi data dengan triangulasi waktu.

\section{Hasil Penelitian dan Pembahasan}

\section{Hasil}

Berdasarkan data dari pertemuan pertama dan kedua, yang diperoleh dari hasil observasi dan hasil wawancara, guru matematika menyiapkan rencana pembelajaran individual (RPP) dan silabus. Sebelum proses pembelajaran berlangsung guru matematika telah menyusun RPP dan silabus. RPP yang digunakan untuk siswa biasa dan siswa ABK sama, namun dalam pelaksanaanya siswa ABK lebih diperhatikan. GPK tidak menyiapkan RPP dan silabus karena sudah disiapkan oleh guru mata pelajaran, serta tidak adanya Program Pembelajaran Individual (PPI) yang diberikan kepada siswa ABK.

Kesiapan lainnya yang dilakukan guru matematika yaitu menyiapkan media dan sumber belajar. Untuk materi lingkaran guru matematika menggunakan media busur, penggaris dan tutup kaleng cat yang berbentuk lingkaran, untuk mengenalkan konsep lingkaran dan menghitung sudut-sudut lingkaran, tetapi tidak menyiapkan media belajar khusus siswa ABK. Sedangkan sumber belajar yang digunakan yaitu buku paket. GPK juga menyiapkan media dan sumber belajar namun hanya untuk siswa $\mathrm{ABK}$ slow learners.

Untuk siswa ABK slow learners, guru matematika tidak menyiapkan media khusus. Media khusus tersebut sudah disiapkan oleh GPK. Media khusus dapat berbentuk koin atau gambar di karton yang berbentuk lingkaran, sesuai materi yang dipelajari, dibuat semenarik mungkin agar ABK slow learners tidak cepat bosan saat pembelajaran. Hal ini diharapkan dengan adanya media khusus, siswa tidak kesulitan dalam belajar atau materi yang disampaikan 
oleh guru matematika dapat diserap dengan baik.

Dalam pelaksanaan pembelajaran pertama guru matematika menyiapkan siswa secara psikis dan fisik sebelum proses pembelajaran. Siswa disiapkan dengan cara memberitahukan materi yang akan dibahas dan guru matematika mengajukan beberapa pertanyaan tentang materi pertemuan sebelumnya, untuk siswa ABK slow learners pertanyaan yang diberikan lebih mudah. Dalam hal ini GPK juga menyiapkan ABK slow learners dengan memberitahu materi pelajaran yang akan dipelajari dan membantu siswa ABK menjawab pertanyaan tentang materi sebelumnya sehingga siswa ABK dapat menjawab pertanyaan tersebut. GPK mencatatkan pada lembar catatan apa saja yang perlu disiapkan agar siswa ABK tidak lupa. Lembar catatan itu juga dapat digunakan orang tua untuk memantau kegiatan yang dilakukan anak mereka di sekolah.

Selain menyiapkan psikis dan fisik siswa, guru matematika juga menjelaskan tujuan pembelajaran dan kompetensi dasar yang akan dicapai sebelum menjelaskan materi yang diajarkan. Untuk hal ini GPK juga ikut serta membantu menjelaskan kepada siswa ABK namun itu hanya berlaku pada pertemuan pertama diawal pembelajaran BAB baru, untuk pertemuan selanjutnya GPK tidak menjelaskan tujuan pembelajaran dan kompetensi dasar yang akan dicapai karena sudah dijelaskan oleh guru mata pelajaran dan sudah dijelaskan dipertemuan pertama.

Dalam kegiatan menjelaskan materi yang akan dipelajari guru matematika mendapatkan bantuan dari GPK, karena ia akan bertugas membantu menjelaskan materi tersebut kepada siswa ABK. Guru matematika menggunakan beragam pendekatan pembelajaran, media pembelajaran dan sumber belajar lain. Pendekatan yang digunakan guru matematika adalah pendekatan yang berpusat pada siswa dengan arahan dari guru matematika maupun GPK untuk ABK. Sedangkan media yang digunakan biasanya guru matematika memberikan media pembelajaran lain dengan menggunakan praktek misalnya pada materi lingkaran seperti mengukur sudut lingkaran menggunakan busur dan jangka. Untuk sumber belajar guru matematika menggunakan buku paket.

Dalam pelaksanaan pembelajaran guru matematika melibatkan siswa biasa atau ABK secara aktif dalam setiap kegiatan pembelajaran dengan memberikan soal secara langsung yang membuat siswa berani berbicara untuk menjawab. GPK juga melibatkan ABK slow learners dalam pembelajaran aktif dengan diberi soal untuk dikerjakan. Jika mereka tidak bisa maka akan dibimbing terus kalau bisa mengerjakan diberi pujian.

Guru matematika dan GPK samasama memfasilitasi terjadinya interaksi antara siswa biasa dengan siswa $\mathrm{ABK}$, antara siswa dengan guru dalam setiap pembelajaran dengan tidak membedakan antara siswa biasa maupun ABK. Selain itu guru matematika dan GPK dalam proses pembelajaran selalu memantau dan membimbing ABK namun yang berperan lebih utama adalah GPK yang menangani ABK slow learners. Guru matematika memfasilitasi siswa biasa dan siswa $\mathrm{ABK}$ melalui pemberian tugas, diskusi untuk memunculkan gagasan baru baik lisan atau tertulis, serta dibantu oleh GPK yang membimbing siswa $\mathrm{ABK}$, sehingga dapat mengerjakan tugas yang diberikan oleh guru matematika.

Guru matematika bersama siswa membuat rangkuman atau kesimpulan pelajaran yang melibatkan siswa biasa dan 
siswa ABK. Saat membuat rangkuman siswa ABK slow learners dibantu dan dibimbing oleh GPK. Tentu tidak mudah mengajak siswa ABK slow learners untuk membuat rangkuman tidak seperti siswa reguler. GPK harus bersabar, pelan-pelan mengajari mereka dan dilakukan berulang-ulang.

Guru matematika melakukan penilaian untuk siswa biasa maupun siswa ABK namun untuk menilai siswa ABK slow learners akan dibantu oleh GPK. Untuk penilaian terhadap siswa ABK slow learners tentu saja berbeda dengan siswa biasa. Penilaian terhadap siswa biasa yang dilakukan oleh guru matematika yaitu menilai hasil kinerja siswa saat pembelajaran dan latihan soal.

Pelaksanaan pembelajaran pada tahap terakhir adalah guru matematika memberikan umpan balik terhadap proses dan hasil pembelajaran dengan memberikan pertanyaanpertanyaan mengenai materi yang telah diajarkan. Untuk siswa ABK proses umpan balik ini akan dibantu oleh GPK. Namun terkadang siswa ABK saat pembelajaran akan berakhir ia akan terlihat sangat tidak fokus, sehingga proses umpan balik kepada siswa ABK tidak terlaksana.

Untuk siswa $A B K$ sendiri pada tahap pelaksanaan pembelajaran ini siap secara psikis dan fisik ketika memulai pelajaran, bisa menjawab pertanyaan dari guru matematika, bertanya kepada guru matematika atau GPK, mengerti tentang tujuan pembelajaran atau KD yang telah disampaikan, senang dan aktif dengan pembelajaran yang dilakukan oleh guru matematika apabila pembelajaran itu dianggapnya mudah, lebih mudah berinteraksi dengan teman sesama jenis, beberapa soal yang diberikan oleh guru matematika dapat dikerjakan siswa ABK, mengerti dengan kesimpulan yang diberikan oleh guru matematika tetapi tidak aktif dalam membuat kesimpulan, terkadang ABK mengikuti proses umpan balik.

Berdasarkan hasil observasi dan hasil wawancara diperoleh data bahwa dalam evaluasi dan tindak lanjut, guru matematika dan GPK tidak merencanakan kegiatan tindak lanjut dalam bentuk pembelajaran remedi, program pengayaan, layanan konseling untuk siswa biasa atau ABK yang mengalami kesulitan, tetapi hanya dengan mengingatkan materi selanjutnya, rencana pembelajaran berikutnya dan memberikan tugas.

Berdasarkan data yang diperoleh dari hasil wawancara bahwa faktor atau kendala yang dialami $\mathrm{ABK}$ slow learners selama proses pembelajaran yaitu $\mathrm{ABK}$ slow learners mengalami kesulitan menanamkan konsep matematika. Hal ini dapat terjadi karena ABK slow learners mempunyai daya ingat yang cukup rendah dan pengetahuan yang kurang sehingga sulit menyiapkan materi yang berbeda. Selain itu selama proses pembelajaran ABK slow learners biasanya kurang percaya diri dalam mengutarakan jawaban karena takut salah dan biasanya kurang fokus pada proses pembelajaran.

Faktor atau kendala yang terjadi guru matematika dan GPK menjelaskan pula untuk penyelesaiannya yaitu dengan melakukan pendekatan yang lebih baik lagi agar siswa ABK dapat tertarik terhadap pembelajaran dan bisa memahami materi yang diberikan. Dalam hal ini GPK sebagai guru pendamping menambahkan memberikan motivasi yang bersifat membangun kepercayaan dirinya dan selalu memberikan semangat pada saat belajar.

\section{Pembahasan}

Proses pembelajaran matematika di kelas inklusif melalui tiga pokok tahapan, 
yakni tahap kesiapan guru sebelum proses pembelajaran, tahap pelaksanaan pembelajaran dan tahap evaluasi dan tindak lanjut selama proses pembelajaran. Hal ini sesuai dengan Permen No. 32 Th 2013 dijelaskan bahwa, "setiap satuan pendidikan melakukan perencanaan proses pembelajaran, pelaksanaan proses pembelajaran, penilaian hasil pembelajaran, dan pengawasan proses pembelajaran untuk terlaksananya proses pembelajaran yang efektif dan efisien".

Sementara itu Majid (2011: 96-97) juga menjelaskan bahwa, "unsur-unsur yang amat penting masuk dalam rencana pengajaran adalah: (1) apa yang akan diajarkan, pertanyaan ini menyangkut berbagai kompetisi yang harus dicapai, indikator-indikatornya, serta materi bahan ajar yang akan disampaikan untuk mencapai kompetensi tersebut; (2) bagaimana mengerjakannya, pertanyaan ini berkenaan dengan berbagai strategi yang akan dikembangkan dalam proses pembelajaran, termasuk pengembangan berbagai aktivitas opsional bagi siswa dalam menyelesaikan tugas-tugasnya; (3) bagaimana mengevaluasi hasil belajarnya, pertanyaan ini harus dijawab dengan merancang jenis evaluasi untuk mengukur daya serap siswa terhadap materi yang mereka pelajari pada sesi tersebut".

$$
\text { Pada Kesiapan sebelum }
$$

pembelajaran, berkaitan dengan proses pembelajaran matematika di kelas inklusif, kesiapa guru sangat diperlukan sebelum dimulainya pembelajaran. Kesiapan guru yang paling penting adalah menyiapkan rencana pelaksanaan pembelajaran (RPP), dalam pembuatannya, seorang guru harus memperhatikan beberapa hal yang sangat menentukan keberhasilan proses belajar mengajar yang sesuai dengan RPP. Di SMPN 5 Banjarbaru, Sebelum pembelajaran dimulai guru matematika menyiapkan RPP dan silabus.
Sebelum proses pembelajaran berlangsung guru matematika telah menyusun RPP dan silabus. Penyusunan RPP biasanya dilakukan setelah selesai satu kompetensi dasar. RPP yang digunakan untuk siswa biasa dan siswa ABK slow learners itu sama, namun dalam pelaksanaannya akan adanya perbedaan dalam segi pendekatan. Dalam penyusunan RPP, guru matematika juga berkomunikasi dengan GPK untuk siswa ABK slow learners.

GPK sebelum proses pembelajaran tidak menyiapkan RPP dan silabus karena sudah disiapkan oleh guru matematika. GPK hanya bertugas membantu menyiapkan siswa ABK slow learners. Kesiapan lainnya yang dilakukan guru matematika yaitu menyiapkan media dan sumber belajar. Sedangkan sumber belajar yang digunakan yaitu buku paket. Selain guru matematika, GPK juga menyiapkan media dan sumber belajar untuk siswa ABK slow learners.

Media khusus dapat berbentuk koin atau gambar di karton yang berbentuk lingkaran, sesuai materi yang dipelajari, dibuat semenarik mungkin agar $\mathrm{ABK}$ slow learners tidak cepat bosan saat pembelajaran. Hal ini diharapkan dengan adanya media khusus, materi yang disampaikan dapat diserap dengan baik oleh ABK slow learers.

Pada pelaksanaan pembelajaran harus disesuaikan dengan kemampuan dan kebutuhan setiap peserta didik. Dalam proses pembelajaran guru matematika harus mampu mengajar setiap peserta didik tidak terkecuali siswa ABK dan dapat merberikan pelayanan sesuai kebutuhan individualnya dalam setting kelas. Kegiatan pembelajaran setting pendidikan inklusif antara lain menerapkan prinsip-prisnsip pembelajaran yang aktif, inovatif, kreatif, efektif, dan menyenangkan (PAIKEM). Dalam pelaksanaan pembelajaran di kelas inklusif SMPN 5 Banjarbaru pertama 
guru matematika menyiapkan siswa secara psikis dan fisik sebelum proses pembelajaran. Siswa disiapkan dengan cara memberitahukan materi yang akan dibahas dan guru matematika mengajukan beberapa pertanyaan tentang materi pertemuan sebelumnya, untuk siswa ABK slow learners pertanyaan yang diberikan lebih mudah. Dalam hal ini GPK juga menyiapkan ABK slow learners dengan memberitahu materi pelajaran yang akan dipelajari dan membantu siswa ABK menjawab pertanyaan tentang materi sebelumnya sehingga siswa ABK dapat menjawab pertanyaan tersebut. Pentingya seorang siswa ABK dapat memberikan suaranya ketika pembelajaran berlangsung karenahal ini dapat membangun kepercayaan dari dirinya. Peran penting terletak pada GPK yang juga bertugas mencatatkan pada lembar catatan apa saja yang perlu disiapkan agar siswa ABK tidak lupa. Lembar catatan itu juga dapat digunakan orang tua untuk memantau kegiatan yang dilakukan anak mereka di sekolah.

Selain menyiapkan psikis dan fisik siswa, guru matematika juga menjelaskan tujuan pembelajaran dan kompetensi dasar yang akan dicapai sebelum menjelaskan materi yang diajarkan. Dengan dibantu GPK yang juga ikut serta membantu menjelaskan kepada siswa ABK. Namun itu hanya berlaku pada pertemuan pertama diawal pembelajaran Bab baru, untuk pertemuan selanjutnya GPK tidak menjelaskan tujuan pembelajaran dan kompetensi dasar yang akan dicapai, seharusnya hal ini harus selalu disampaikan oleh GPK kepada siswa ABK.

Hal yang terpenting adalah guru dapat menggunakan beragam pendekatan pembelajaran, media pembelajaran dan sumber belajar lain. Pendekatan yang digunakan guru matematika adalah pendekatan yang berpusat pada siswa dengan arahan dari guru matematika maupun GPK untuk ABK. Sedangkan media yang digunakan biasanya guru matematika memberikan media pembelajaran lain dengan menggunakan praktek.

Dalam pelaksanaan pembelajaran guru matematika melibatkan siswa biasa atau ABK secara aktif dalam setiap kegiatan pembelajaran dengan memberikan soal secara langsung yang membuat siswa berani berbicara untuk menjawab. GPK juga melibatkan ABK slow learners dalam pembelajaran aktif dengan diberi soal untuk dikerjakan. Jika mereka tidak bisa maka akan dibimbing terus kalau bisa mengerjakan diberi pujian.

Peran penting yang harus dilakukan Guru matematika dan GPK ialah sama-sama memfasilitasi terjadinya interaksi antara siswa biasa dengan siswa $\mathrm{ABK}$, antara siswa $\mathrm{ABK}$ dengan guru dalam setiap pembelajaran dengan tidak membedakan antara siswa biasa maupun ABK. Selain itu guru matematika dan GPK dalam proses pembelajaran selalu memantau dan membimbing ABK namun yang berperan lebih utama adalah GPK yang menangani ABK slow learners.

Guru matematika bersama siswa membuat rangkuman atau kesimpulan pelajaran yang melibatkan siswa biasa dan siswa ABK. Saat membuat rangkuman siswa ABK slow learners dibantu dan dibimbing oleh GPK. Tentu tidak mudah mengajak siswa ABK slow learners untuk membuat rangkuman tidak seperti siswa reguler. GPK harus bersabar, pelan-pelan mengajari mereka dan dilakukan berulang-ulang.

Penilaian yang dilakukan oleh guru matematika dengan GPK tentunya berbeda karena Guru matematika akan melakukan penilaian untuk siswa biasa maupun siswa 
ABK, sedangkan GPK hanya akan bertugas menilai siswa ABK. Untuk penilaian terhadap siswa ABK slow learners tentu saja berbeda dengan siswa biasa. Penilaian terhadap siswa biasa yang dilakukan oleh guru matematika yaitu menilai hasil kinerja siswa saat pembelajaran dan latihan soal.

Adanya kendala dalam siswa ABK yang biasanya akan kehilangan fokusnya terhadap pembelajaran pada tahap terakhir mengakibatkan gagalnya proses umpan balik yang dilakukan guru matematika maupun GPK terhadap siswa $\mathrm{ABK}$, hal ini perlunya peran penting GPK untuk tetap menjaga siswa ABK agar tetap fokus sampai berakhirnya pembelajaran.

Seorang ABK tipe slow learners Dalam beberapa hal mengalami hambatan atau keterlambatan berfikir, merespon rangsangan dan adaptasi sosial, tetapi masih jauh lebih baik dibanding dengan tunagrahita, lebih lamban dibanding dengan peserta didik pada umumnya, mereka butuh waktu yang lebih lama dan berulang-ulang untuk dapat menyelesaikan tugas-tugas akademik maupun non akademik, sehingga memerlukan pelayanan pendidikan khusus" (Kustawan, 2012: 29).

Dalam tahap ini guru matematika dan GPK tidak merencanakan kegiatan tindak lanjut dalam bentuk pembelajaran remedi, program pengayaan, layanan konseling untuk siswa biasa atau ABK yang mengalami kesulitan, tetapi hanya dengan mengingatkan materi selanjutnya, rencana pembelajaran berikutnya dan memberikan tugas. Seharusnya guru matematika dan GPK dapat merencanakan layanan konseling bagi siswa yang mengalami kesulitan dalam belajar, terutama siswa ABK yang perlu diberi perhatian khusus.

\section{Simpulan dan Saran}

\section{Simpulan}

Berdasarkan hasil penelitian dan pembahasan dalam pembelajaran matematika pada Anak Berkebutuhan Khusus (ABK) di kelas inklusif SMPN 5 Banjarbaru tahun pelajaran 2016-2017, proses pembelajaran inklusif melalui tiga pokok tahapan, yakni tahap kesiapan sebelum proses pembelajaran, tahap pelaksanaan pembelajaran, serta tahap evaluasi dan tindak lanjut.

Pada kesiapan sebelum pembelajaran, Guru matematika menyiapkan RPP, silabus, media dan sumber belajar. Sedangkan GPK hanya bertugas menyiapkan media, sumber belajar dan siswa ABK slow learners itu sendiri. Sumber belajar yang digunakan yaitu buku paket. Media khusus dapat berbentuk koin atau gambar di karton yang berbentuk lingkaran, sesuai materi yang dipelajari.

Pada pelaksanaan pembelajaran, Guru matematika menyiapkan siswa secara psikis dan fisik, memberitahukan materi yang akan dibahas dan mengajukan beberapa pertanyaan tentang materi sebelumnya, menjelaskan tujuan pembelajaran dan kompetensi dasar. Guru matematika menggunakan beragam pendekatan, media dan sumber belajar lain baik untuk siswa biasa maupun ABK slow learners, serta memfasilitasi terjadinya interaksi di dalam kelas, serta selalu memantau dan membimbing ABK. Guru matematika bersama seluruh siswa membuat rangkuman atau kesimpulan pelajaran dan melakukan Penilaian untuk seluruh siswa, serta memberikan umpan balik terhadap proses dan hasil pembelajaran. Sedangkan GPK bertugas menjelaskan kembali kepada siswa ABK slow 
learners tentang apa saja yang disampaikan guru matematika di depan kelas,serta bertugas menilai siswa ABK.

Pada tahap Evalusi dan tindak lanjut, Guru matematika menyampaikan materi selanjutnya, rencana pembelajaran berikutnya dan memberikan tugas. GPK juga ikut menyampaikan materi selanjutnya, rencana pembelajaran berikutnya kepada siswa ABK slow learners.

\section{Saran}

Agar proses belajar mengajar di kelas inklusif dengan baik dan tujuan yang diinginkan dapat tercapai, maka disarankan: (1) bagi sekolah, partisipasi seluruh pihak sekolah harus lebih maksimal sehingga kualitas sekolah dan prestasi siswa di kelas inklusif terutama siswa ABK tidak kalah dengan siswa biasa lainnya, serta pihak sekolah mungkin perlu membuat ruangan Puspa atau ruang pusat pelayanan $\mathrm{ABK}$ untuk memberikan layanan terbaik bagi siswa $\mathrm{ABK}$; (2) bagi guru, hendaknya seorang guru dapat menggunakan cara pendekatan pembelajaran yang tepat bagi siswa $\mathrm{ABK}$ dan bisa selalu mengajak siswa biasa maupun siswa ABK untuk berpartisipasi aktif dalam pembelajaran matematika antara lain dengan selalu memotivasi siswa terutama $\mathrm{ABK}$ slow learners sehingga mempunyai semangat tinggi dalam belajar; (3) bagi GPK, penyelesaian yang diberikan untuk mengatasi kendala yang dialami siswa ABK slow learners perlu dikembangkan agar tidak ditemukan lagi kendala saat proses pembelajaran selanjutnya dan dapat membuat Program Pembelajaran Individual (PPI); (4) bagi peneliti selanjutnya, hendaknya melaksanakan penelitian pada siswa ABK lainnya dengan jenjang pendidikan yang lebih tinggi.

\section{Daftar Pustaka}

Hasratuddin. 2014. Pembelajaran Matematika Sekarang dan yang akan Datang Berbasis Karakter, Jurnal Didaktik Matematika, (Online), Vol.1,No.2, (http://jurnal.unsyiah.ac.id/DM/article/vi ew/2075, diakses 28 November 2016)

Kustawan, Dedy. 2012. Pendidikan Inklusif dan Upaya Implementasinya. Jakarta: Luxima Metro Media

Majid, Abdul.2011. Perencanaan Pembelajaran Mengembangkan Standar Kompetensi Guru. Bandung: PT Remaja Rosdakarya Offset

Ngadimun et.al. 2013. Pedoman Teknis Penyelenggaraan Pendidikan Inklusif Propinsi Kalimantan Selatan. Banjarmasin: Dinas Pendidikan Kalimantan Selatan Pokja Pendidikan Inklusif

Peraturan Pemerintah Republik Indonesia Nomor 32 Tahun 2013 tentang Perubahan Atas Peraturan Pemerintah Nomor 19 Tahun 2005 Tentang Standar Nasional Pendidikan. 2013. (Online), Jakarta:Pemerintah, (https://www.slideshare.net/iwansukma/ pp-no-32-tahun-2013-tentang-standarnasional-pend, diakses 13 Juni 2017)

Setyowati, Liling Kristin. 2014. Analisis Kesulitan Anak Berkebutuhan Khusus Dalam Belajar Matematika di Kelas Inklusi (Penelitian Dilaksanakan Di SMK N 9 Surakarta. (Online), Surakarta: FKIP Universitas Muhamadiyah Surakarta, (http://eprints.ums.ac.id/28712/12/NAS KAH_PUBLIKASI.pdf, diakses 21 November 2016) 